DOI: $10.26907 / 2311-2042-2020-15-2-18-33$

\title{
THE USE OF SIZE ADJECTIVES IN THE TATAR AND ENGLISH LANGUAGES
}

\author{
Gulnara Firdavisovna Lotfullina, \\ Kazan State Power Engineering University, \\ 51 Krasnoselskaya Str., Kazan, 420034, Russian Federation, \\ gflutfullina@mail.ru.
}

Ruzilya Rashitovna Salakhova, Kazan Federal University, 18 Kremlyovskaya Str., Kazan, 420008, Russian Federation, ruzilya5@mail.ru.

Guzel Zufarovna Gilazieva, Kazan State Power Engineering University, 51 Krasnoselskaya Str., Kazan, 420034, Russian Federation, gilyazieva78@mail.ru.

\begin{abstract}
The article discusses comparative aspects of size adjectives related to the human environment. The study of the adjectives that describe the size of objects in the Tatar and English languages, along with clarifying many issues in the area of vocabulary and semantics of the two languages, helps indicate common and distinctive features in both languages, that differ in their structures, and determine the frequency of their use in speech. This explains the relevance of the topic in modern linguistics.

The article studies scientific aspects of the main features characterizing adjectives that describe a person's appearance and wardrobe. The adjectives under consideration represent such components as big, wide, little, small, long/tall, and short; the samples that determine the use of these patterns were obtained from the national corpora of the Tatar (Tatar National Corpus "Tugan Tel") and English (British National Corpus) languages. The article identifies positive and negative types of size adjectives, based on the corpora data.

The practical significance of the research is determined by the use of the material under study in the methodology of teaching the Tatar and English languages and in further studies in lexicology, semasiology, and stylistics of the language.
\end{abstract}

Key words: size adjectives, positive size adjectives, negative size adjectives, collocation, frequency of use.

Language and social life are closely connected. Language mirrors various aspects of human activities and their correlations with society, nature, and environment. These correlations can be identified only through a comprehensive study of the semantic features of the linguistic components. There are no scientific studies in Tatar linguistics that analyze adjectives, describing physical characteristics of people with adjacent objects and spatialdimensional relations. Objects are characterized by their dominant size traits. For example, biyek yurt (a high house) looks higher than the standard height for a building; if houses are large and long, the height trait is not used in their descriptions. The onomasiological framework involves studying attributive adjectives in the opposite direction, i. e. from a concept to its definition. The semasiological approach is mainly based on identifying descrip- tive features of adjectives. The scientific novelty of this article is its comparative study of the adjectives that point out size traits of objects related to the human environment through the onomasiological approach. Therefore, our object of study is adjectives, the subject of the research is their content and definition. We analyzed the size attributes related to everyday life and people's environment using the method proposed by G. I. Kustova.

First of all, we focus on size adjectives that define an "immediate environment" of a person. Clothing, shoes, and jewellery are considered to be close contact objects. The attributes, characterizing these objects, do not apply directly to specific people; however, they certainly have a prototypical measuring unit. In other words, when people use certain things, keeping their own body features in 
mind, they pay attention to their length, width, and size. For example, long necklaces are usually chosen according to the external traits of one's neck; when wearing long dresses or trousers, the body height and the length of the legs are taken into account. Considering toiletry as an example:

Itek ochy altyn chachakly ak atlas koulmek, altynsu efek bilbau, jing ochlary, yaka turlary uka belen chigelgen kuye kyzyl toustege barhet kamzul kigen, muenga zatly kaptyrma belen elekterelgen, ere tamgaly enje-brilliantlar belen zinnetlengen kin' muensa, bashyna jem-jem kilep torgan, enjebrilliantlar belen bizelgen, ouchy un' yakka salynyp torgan kalfak kigen (M.Galiev. Talisman).

Ak batist yaulygyn kara kashlary oustennen gene artka kaitaryp beilegen, yakasy achyk, kyska jin'le tar koulmek kiep, jiyerchykly muenyna vak merjennen kechkene muensa takkan, simez belegene kara komesh belezek kigen (A.Yeniki. "Saz Chechege").

If their complexion was their most celebrated feature, then perhaps a long necklace of perfect pearls (8S2) [6].

Bare shoulders and arms; a heavy gold and ebony bracelet; an enormously long necklace of what looked like sapphires, though I presumed they must be paste (G13) [6].

The length trait of the mentioned jewellery item is described based on the traits of a person's neck. The word muensa (a necklace) occurs 109 times in the Tatar language, yet only two examples with size adjectives have been found: kin' muensa (a wide necklace), kechkene muensa (a small necklace). In English, for instance, a necklace is rarely used with size adjectives: long necklace -two uses, short necklace -none. Accordingly, the length attribute for a necklace can be considered insignificant in the Tatar language. This, to an extent, suggests that there is some kind of stereotypical length that is traditionally fixed in people's mindsets.

\section{Wardrobe}

Kerim abyi kin'ashen iste totyp, ousteme kiyese nerselerne sailap aldym: kara barhetten tar gyna ozyn kulmek, biek ukchele tufliler, kechkene enjele kalfak. (E. Yeniki. Golendem Tutash Khetirese).

Mar'jambanu bouten tenen kaplap torgan ozyn kulmek kigen, bashyna, chech mueny kurenmeslek itep, ak yaulyk bourkengen (F. Bayramova. Son'gy Namaz).

A yanyn'da torgan avyl kyzynyn' cherkilerge ise de kitmi, bary tik ara-tire gene bolay da kyska kulmek itagen kutarep, ak baltyrlaryna kungan edepsez cherkinen bashyna jite ( $\mathrm{H}$. Ahmadiev. Ambirak, Yaki Kara Kaen Kiyssasy).
Ak toustege kyska chalbar kigen, jin'sez bluzkasyn da jilkesene elengen ike tar tasma gyna totyp tora (M. Amirkhanov. I Kylgan Dogam Minem).

Belki, alar kolkhozynyn' sierlarynnan saugan soutler de mene shulai shesheler belen monda kileder de, anyn' kem kulynnan chykkanyn uilap tormastan, tezden yugary kyska chalbar kigen, $k a-$ ra kuzlekle, jonly baltyrly shushy ademner echep kuyalardyr (M. Magdiev).

Sounds like she's got a flipping long dress on and a straw hat (KCE).

We had worked a big ball in the wintertime, when you went with your long dress on, and your gloves, you know your (H05).

Mrs Lynde looked at the thin little girl in the short dress, with her freckled face and red hair (FPT).

Lower at the back, the short dress's absolute simplicity contrasted effectively with the extravagant colour, a deep rich crimson (H9L).

Because he always had long trousers that went over his boots, and they were you know, very wide (G64).

(2) They were real grown-up long trousers exactly like those worn by the boys at the big school (ACW).

Ordinary women's clothing is described by the size adjectives that determine its length; as mentioned above, it depends on a person's height. The study has shown that positive size adjectives are used 4-5 times more often than negative size adjectives in both languages. The comparative analysis results, concerning the frequency of the use of size adjectives in Tatar and English, indicate that this type of adjectives is used twice less often in English. Here are some examples: long dress - 22 uses, in Tatar: ozyn kulmek - 39 uses. When it comes to negative size adjectives, they are equally common in both languages: short dress - 5 uses, kyska kulmek -7 uses. It is worth saying that the typical dress in the Tatar language is much longer than in English; this can be explained by the positive connotation of a long dress among the traditional clothing of the Tatar people.

The trousers, as ordinary men's clothing, were not chosen by chance since their length is usually determined by the part of the body from the hip to the ankle. In the Tatar language, only a few examples of trousers, characterized by their length, have been found: ozyn chalbar - one use, kyska chalbar - 6 uses. Negative size adjectives are used twice more often in English: long trousers - 13 times, short trousers -29 times. The use of this adjective 
implies a negative connotation, as the typical length attribute of trousers must match the length from one's hips to one's ankle.

\section{Headgear}

Tavyshka zur mamyk shel yabyngan enise ut kabyzgan iken (S. Sharipov. Hushlashmiym).

Yan'agyn zur yaulyk belen beylegen Sheyhetdinov kere (T. Gizzat).

Bashyna ul chechen berge tuplap kyska gyna yaulyk beylep kuygan, oustene ere chechke tousherelgan kyska itekle sitsy kylmek hem irken balakly ozyn chalbar - sportsmennar chalbary itep kuygan ide (H. Fattah. Saylanma Eserler).

Why did they last minute put this long scarf around her neck, hmm? (8S2).

All I know is he has big, protruding eyes and he wears a funny-looking, short, white scarf (ACW).

The results of the study have shown that the words denoting women's headwear are more widely used in the Tatar language than in English, which is explained by national and religious features characterizing the Tatar people. The positive size adjective zur yaulyk (shel) occurs 17 times; the negative size adjective kyska yaulyk - 4 times. Collocations such as kechkene yaulyk have been found as well; however, the word yaulyk denotes a handkerchief in those cases. It is also important to note that Tatar women used to wear kalfaks (traditional Tatar women's headdress) on top of their scarves or shawls. For the most part, the adjectives that describe a kalfak denote decoration, colour, and luxuriousness of this national headdress; however, although rare, there are cases of collocations with negative size adjectives, such as kechkene, neni:

Kyznyn' bashynda - touse haman uzgermegen neni yashel kalfak (R. Garif. Oulmesbike).

Kechkene gene kalfak kiya, atasy kurmegende mandolina uynap ta jibere (G. Ibragimov. Yeshler).

In English, a scarf is often seen as a women's headdress, it is described by a variety of adjectives, yet very few examples have been found of its use next to size adjectives. Scarves are mainly characterized by their length features. A long scarf is considered a collocation with a positive size adjective. In our research, it appears 6 times in the corpus; collocations with a negative meaning, such as in $a$ short scarf, occur 3 times.

\section{Footwear}

Kysyp torgan yaise artyk zur ayak kieme selametlek ouchen ziyanly (A. Sitdikova. Selametlek - Ukche Astynda!).
Ayagyna kap-kara zur itek, oustene alama syrma, bashyna yolkysh burek kigen miekly ir stroydan yougerep chyga da, tezen kochaklap, jepshek karga iele (S. Sharipov).

She thinks she's tall. Look at his big shoes. So what, so what say it right here (KPE)

Half consisted of a short, black skirt and plump legs tapering to absurdly small shoes (GW3).

The only blots on the landscape were a pair of small shoes beside the Aga and a nylon ski-jacket airing on the back of a chair (JYC).

In our opinion, there is no need for the distinctive analysis of men's and women's footwear, since the size of a shoe is determined by the size of the sole. Besides, the size of shoes is very rarely used to describe people in both Tatar and English: big shoes - 1 case, small shoes - 2 cases; zur ayak kieme - 6 cases, kechkene ayak kieme - 1 case. Unlike English, the word itek (boots) is frequently used in the Tatar language (551 times). Only one size adjective describing the length measurement has been found and this trait is determined by the length of the sole. Accordingly, a shoe and its size are equal to the size trait of the sole.

Bootleg shoes, such as the word itek, can be used with other types of size adjectives:

Lesnikovnyn ayagynda - ozyn itek, buinnary yalgana torgan spinning tagylgan jeben belegene elgen, jylyrak keingen (S. Sharipov. Hushlashmiym).

The word itek, despite its high frequency of the use (551 times), rarely collocates with size adjectives. The use of the size adjective, given in the last example (ozyn itek), is determined by the length of the calf. Another interesting fact is worth mentioning in relation to the Tatar language: there are many patterns in which footwear bashmak (59 times), chuak (24 times) are used; however, no cases of their use with size adjectives have been found.

\section{Food}

"Food is material, it has its own weight, although a person does not put it on himself, he puts it inside," - says I. G. Kustova. There is a certain set of common features that describe food, which is the reason why dishes rarely collocate with three-dimensional attributive adjectives. For example, zur tort (a big cake) does not express the certain size of this dish, but rather the scale of the celebration. In the Tatar and English languages, such collocations as Big Mac, vak balesh are very common; however, in these cases, the adjectives big and vak do not indicate the size of these dishes, 
since both words are used as a part of the name of a certain dish.

Well, we don't have it on Sunday because we always have a great big lunch (KBB).

I can't eat it. I don't think so, he had a big lunch $(\mathrm{KCV})$.

As can be seen from the examples above, the adjective big in English can be often found on the McDonald's menu: Big Mac, Big Tasty, etc. In terms of the frequency of their use, the most common phrase in the English corpus is big mac, which has 41 instances, and is followed by the collocation big lunch that appears 6 times. They are both considered to be positive size adjectives.

Celebration cakes are rarely described by their large size traits in English: a big cake appears six times, a small cake - 12 times. As we see, negative connotation predominates here, although it is important to note that there is another word a cupcake that implies a small size of the desert.

Tabyn urtasyna khush islere an'kyp torgan choumekle zur balesh chygaryldy. (R. Nizami. Bez Yashibez).

Kvartirga kunak eget kaytasy bulgach, Gainelvafa karchyk bozauny abzarga chygargan, sap-sary itep baskychlarny, idennerne yugan, vak balesh peshergen ide. (M. Magdiev. Frontoviklar).

Karchyk kisherne turap, an'ardan zur balesh peshergen. (C. Saubanova. Ekiyatler)

Ak ebi irten Goylemdarny vak peremech belen syilady (A. Timergalin. Karaurman Asha).

Vak kyna koumech yaki bavyrsak. (G. Ishaki. Kejoul Chitek).

The examples indicate that among the adjectives that determine the size of a dish, the use of the adjective $v a k$ is widespread in the Tatar language; the word occurs in 2692 patterns. Mostly, size adjectives (zur balesh, vak balesh) are used to name the dishes. Only in collocations, mentioned in the last three sentences (zur balesh, vak peremech, vak bavyrsak, vak kumech), the size of the dish is implied.

Thus, in the course of our study, based on the frequency-dependent selection method, 300 phrases with size adjectives have been analyzed and most of them are food names.

Unlike English, in the Tatar language, the main dish that determines the importance and magnitude of a celebration is not a cake, but a balesh. Therefore, according to the rules of logic, we expect it to be defined by a positive size adjective; however, the collocation zur balesh occurs only in 5 patterns. In our opinion, the name of this national dish itself specifies its large size. This hypothesis might explain the frequent use of the negative size adjective in the expression vak balesh: vak balesh occurs 16 times. The remaining collocations are more uncommon, for example, vak peremech -3 times. The collocation zur peremech is not used at all. It is also worth noting that when describing pastries, the adjective vak does not imply any negative connotation, but only adds a neutral overtone to the description. In other cases, when evaluating other dishes, negative size adjectives usually have a negative connotation.

\section{A person's body}

Size adjectives usually describe both the human body and the parts of the body. Size traits of a person's body are characterized by such adjectives as ozyn (tall) and taza (chubby), yet it is important to remember that size characteristics depend on an individual's subjective point of view and the way people perceive themselves. Here are some examples:

Ozyn chech ustererge rouhset itmiler ide ul chakta (Z. Mahmudi. Khiyalyi).

Dores, kaychagynda kysterep atasy kilgen minutlary da bula kyznyn', yanese, kyska chech bulsa, meshekate ezrek (A. Ahmetgalieva. Sinen Ouchen Yashim).

Zur kuzle, kon'gyrt kalyn tolymly, toz ozyn ayakly, ap-ak tenle ber kyz iken. (M. Magdiev. Frontoviklar).

Biek kutertmele ayak kieme kigen khatyn-kyz uzenen' tebenek buily hem kyska ayakly ikenen kursetep yori (R. Batulla. Saylanma Eserler).

Echendege tyshynda bulgan, uylagany shunduk teleno chykkan Nuriya bala chakta toryp kaldy, апyњ urynyna kinet suzaep kitken, ozyn kully, ozyn ayakly, ozyn muenly (abau!) bereu peyda buldy (G. Yakupova. Ertkych Kany)

Jyelgannar yarym koulemserep ber-bersene karashtylar, turde utyrgan, shere tene zen'ger suretler belen bizelgen, kin' kukrekle, kyska kully bende chert itep toupchegen pochmakka ochyrtty.

(A. Gilazov. Balta Kem Kulynda?)

As it was mentioned before, length, height, and width are considered to be spatial dimensional adjectives. They can be seen and observed. If it is possible to describe the object by its length, the adjective long can be used. Many objects obtain their length trait only through comparison. Take, for example, the collocation ozyn tolym (long hair), it is distinguished by being longer than other person's hair:

Kylanu gyna bulgan iken, berazdan kayadyr jyenganday kinet turaep, ozyn kara chech tolymnaryn retlerge kereshte. 
Ikesende de kyska tolym, ayaklarynda kileshle kette chuekler, ouslerende jin'el chuar kylmek (N. Kashtanov. Paromda).

Here are examples from the English language:

He's got long hair and all (KB1).

Short hair or long hair or just a man? (KCV).

Short hair like a bit of a moron? (KDM).

You'll grow up to be an ugly wizened little monster with short arms and a big head (ACW).

On the landing, a new thought occurred to her and she re-entered, her long arms swinging, her face screwed up with anger (ASS).

It was summer and the only time the air moved was when Zervos waved his short arms or a truck went past outside (C86).

His big body and large head topping the back of it while his short legs hardly touched the floor (CK9).

I can imagine you in a tennis dress. You have such long legs." My knees are knobbly,' she said firmly (A0R).

Based on the observations of both languages, the following conclusions can be drawn.

The type of collocations, consisting of the names and size traits of the human body parts, are widely used in both languages. They characterize a person's appearance according to its specific features. Particular body features, that are relatively larger or smaller than certain aesthetic norms, destroy the commonly accepted body image, for example, zur bashly (big-headed), ozyn kolakly (longeared), etc. Ethical standards account for a neutral description of every part of the body without specifying whether or not they fit normal body proportions.

There are a large number of adjectives that express the length attribute of a person's body in the English language. From the results of the study, it follows that the adjectives that have mostly positive size traits are more common in this language. For instance, the adjectives, describing a person's arm length appear 3 times, leg length - 5 times, and hair length occurs twice as often.

long hair-271 times; short hair- 109 times;

long arms - 33 times; short arms - 11 times;

long legs - 155 times; short legs - 30 times.

A large number of such collocations can be explained by the fact that people pay close attention to themselves and their environment.

The frequency of the use of size adjectives, describing human body parts in the Tatar language, is 5 times lower than in English:

ozyn chech - 47 times; kyska chech - 11 times; times;

ozyn ayakly - 34 times; kyska ayakly - 20

ozyn kully - 19 times; kyska kully-once.

It is noteworthy that in the Tatar language, most of the negative size adjectives that characterize legs are often used with a particular object (for example, kyska ayakly oustel (a table with short legs), etc.) or animals (kyska ayakly et yaki syer (a short-legged dog or cow), etc.).

It is inappropriate in Tatar culture to pay especially close attention to a person's appearance; we believe that the rare use of adjectives in descriptions of a person's appearance is related to this peculiarity.

A person's facial features can be characterized by a variety of adjectives. The overall size of the face is the indicator that determines the size of its other parts; for example, it can be an indicator of such features as zur (tar, kin') man'gay (a large/ narrow/ wide forehead), zur (kechkene) kouz (a big/ small eye), zur (ozyn, pochyk) boryn (a big/ long/ angular nose). In these examples, size adjectives such as wide, large, long are used based on the size (bigness) of the face.

Tege-bu turynda souileshteler, kouleshteler, lekin yan'adan muzyka uinyi bashlagach ta, zur borynly eget berenche bulyp Rafiganyn' kulynnan totyp ta aldy, jilteretep, bouterelderep, urtaga kerep te kitte (N. Fattakh. Saylanma Eserler).

Gud bai! - dip heter yanady kalun balta youzedey rehimsez chyraily, zur borynly latysh, hem kurkytyp chygyp ta kitteler $(\mathrm{H}$. Kamalov. Saylanma Eserler).

Durt ai uzgach ta, kurshe Min'lebike abystay Tatanyn' uzennen un yash chamasy yashrek, ak kyna chyraily, beren'ge almasy kebek tugerek kechkene borynly, yashkelt kouzle ber khatynny iyarte kerde. (A. Bayan. Toulke Totu Kyen Tugel).

Chounki bezde khezer kechkene borynly yahudler, zen'ger chechle tatarlar, kysyk kuzle uryslar hem sap-sary bashly negrlar kubeide (K. Karimov. Telen'ne kurset...).

Askarak salyngan irennere belen zur avyz echenda tezelgen ak, ozyn teshler, ut uynap Torgan yalkynly zur kyzler, bigrek te, ut chygarganday katy, utken, tiz basa torgan yomry, kechkene yaltyr toyaklar anyn' bu kin' dalada bik kup jylkylarga alyn birmes yougereklegen kurseteler ( $\mathrm{G}$. Ibragimov. Kazak kyzy).

Uze kebek uk zur kuzle, olyrak avyzly tomrap torgan uly dounyaga kilgende, Akhteri Berlin yanynda, belekei gene ziratta, chit ilnen' salkyn tufragynda yata ida inde (A. Gyulzev. Terezeler). 
Kechkene avyz, susyl irenner, guya ul salam kabyp zatly kokteil' yotarga gyna yaratylgan (S. Sharipov Khushlashmyim).

Ramil ul arabyzda in' ozyn buyly, zur bashly, zur kuzle, kin in'sele taza hem batyr malay ( $\mathrm{R}$. Faizov. Bez - Ouch Dus).

Ul mejleste kechkene kuzle ber bala bar ide (K. Nasyiri. Saylanma Eserler)

Chiertsen kan chygarga torgan kyp-kyzyl chyraily, dun'gyznyky kebek kene kechkene kuzle yuan mayor akyra iken (I. Sirazi. Ber Utyru - Ber Gomer).

In the Tatar language, positive size adjectives are especially common when describing nose and eyes, and we have found that they are used 3 times more often than the size adjectives that denote facial parts such as mouth and ears.

zur borynly - 31 instances; kechkene borynly 5 instances;

zur kuzle - 34 instances; kechkene kuzle - 5 instances; belekei kuzle - 0;

zur avyz - 11 instances; kechkene avyz - 1 instance;

zur kolakly - 11 instances; kechkene kolakly 2 instances.

Here are some examples from English:

He's got a big nose, got big ears (KP3).

Boyfriend said I'm a common cow and have got a big nose (KPG).

Moxie was curly and glossy, his face with high cheekbones and small nose and small sensuous mouth and dark blue eyes had resumed its glowing charm (APM).

Her features were classically beautiful: the perfectly structured high cheekbones, a small nose, sensual mouth and mesmerizing oval-shaped green eyes (ECK).

She don't say nothing to me, she just looks at me with these big eyes (A74).

Dark girl dressed in scarlet who had a big head, big eyes (her best feature), a big nose and a very big voice (ABW).

A slow deliberate talker, he fixed his small eyes on the subject he was conversing with, as though exerting a hypnotic effect (ARK)

Cynthia and her father coloured hotly, Basil glowered, and Mrs Blessington- Dalrymple's small eyes snapped angrily (BMU).

I love your hairy chest, I love your bi-but I love your big ears, I love you (KB8).

Big nose, big ears, big, big mouth! (KDA).

God had never invented a woman with small ears! (KD8).
It stuck tiny thumbs in small ears, wagged its fingers, and put out its tongue (CEU).

The group of phrases, describing a person's facial features, is widely used in English. From the above examples, it follows that positive size adjectives are used equally often with all parts of the face. Adjectives with negative size traits can be observed when describing such organs as nose, ears, mouth, and eyes, although they are significantly far behind positive size adjectives in terms of their frequency of the use. For instance, negative adjectives associated with nose are 4 times less common, those that describe ears - 10 times, and those that describe mouth are 3 times less common. Only in collocations with eyes, the use of negative size adjectives is 3 times more common than that of positive size adjectives:

big nose - 27 times; small nose - 7 times;

big eyes -33 times; small eyes -21 times;

big ears -49 times; small ears -4 times;

big mouth - 50 times; small mouth - 15 times.

Thus, in English, much attention is paid to the description of a person's face, and its specific parts are described in detail using size adjectives.

After reviewing size adjectives related to the human environment in both languages, we have come to the following results:

- The semantic properties of size adjectives are extremely complex. In this case, first and foremost, it is important to determine the standard size traits for a particular object. If the feature meets the specific standard, the object is characterized by a positive adjective, if it does not meet the standard, it is considered to be a negative trait. However, every nation determines these attributes based on their own point of view. For instance, the negative size adjective used in the collocation vak balesh, which is the national dish of the Tatar people, does not indicate the size of the dish, although other nations may interpret it as a negative size adjective.

- Size adjectives for some nouns are not limited to large and small, they are also characterized by such adjectives as wide, narrow, long, short. The more size adjectives are implicated, the more precise is the definition of the object. We must also keep in mind that there are antonymic (big - small; long - short) or synonymous (big, large, giant; small, little, tiny) adjectives that imply the same size traits. Therefore, as mentioned before, it is of great importance to analyze size adjectives using the onomasiological approach. This approach grants determination of the use of size adjectives in figurative forms as well. To be more specific, if we look into the examples, related to the body from 
the Corpus of the Tatar Language, such collocations as kin' avyzly, tar avyzly, zur avyzly (with a wide mouth, with a narrow mouth, with a large mouth) are applied not to a person, but to other objects. For example: Kechkene gene, tar avyzly kuvshin ide ul (R. Sagdi. Irdeukeler). Shulay da tabaktai oly avyzly kekre torbalarny hem akkosh muenyday sygylmaly skripkalarnyn' ni ikenen aera ide (R. Nizami. Bez Yashibez). There are quite a lot of such examples in English, and, in our point of view, this topic should be scientifically studied.

- As for the structure of size adjectives, their structural features are determined depending on the features of each language, in our case, Tatar and English. There are many similar aspects, yet it does not mean that there are no differences. For example, a description of a person's appearance and body constitution is mainly given by using compound adjectives in the Tatar language. This type of size adjectives is created using the combination formula collocation $+-l y /-l e$, where a collocation turns into a compound adjective by adding a syllable: ozyn kouzle, zur kuzle, kyska chechle, etc.

- Attention is also paid to the frequency of the use of size adjectives in both languages and the results have been highlighted through the statistical approach. Generally speaking, the differences in this matter between Tatar and English are more common. For instance, when it comes to the total number of adjectives that describe a person's appearance in each of the two languages, collocations with size adjectives in the Tatar language are 20 times less frequent than in English. We believe that this phenomenon should be understood not as a sign of neglect with respect to a person's appearance, but as an ethical restraint shown by the Tatars when describing other people.

All things considered, the identification of size adjectives should be based on structural and semantic features of the linguistic components that indicate size traits of objects, along with the peculiarities of their use in the language.

\section{References}

Apresian, Yu. D. (2009). Issledovaniia po semantike i leksikografii [Research in Semantics and
Lexicography]. Moscow, Iazyki slavianskikh kul'tur, T. 1, 568 p. Paradigmatika. (In Russian)

British National Corpus. Elektronnyi resurs. URL: http://www.natcorp.ox.ac.uk (accessed: 26.08.2019). (In English)

Cruse, D. A. (1986). Lexical Semantics. 234 p. Cambridge, Cambridge University Press. (In English)

Dirven, R., Taylor J. R. (1988). The Conceptualisation of Vertical Space in English: The Case of Tall. Topics in Cognitive Linguistics. Ed. by B. RudzkaOstyn. Pp. 379-402. Amsterdam - Philadelphia, John Benjamins Publishing Company. (In English)

Kennedy, Ch., McNally L. (2005). Scale Structure, Degree Modification, and the Semantics of Gradable Predicates. Language. Vol. 81. No. 2, pp. 345-381. (In English)

Kuzina, I. Yu. (2011). O parametrizatsii deistvitel'nosti iazykovymi sredstvami v khudozhestvennom diskurse (na primere epistoliarnogo zhanra opisaniia avantiurnogo puteshestviia) [On the Parametrization of Reality by Linguistic Means in Fictional Discourse (based on the epistolary genre of an adventurous journey description]. Vestnik Orlovskogo gosudarstvennogo universiteta. Seriia "Novye gumanitarnye issledovaniia". No. 1 (15), pp. 161-165. (In Russian)

Kustova, G. I. (2004). Tipy proizvodnykh znachenii i mekhanizmy iazykovogo rasshireniia [Derived Value Types and Language Extension Mechanisms]. 472 p. Moscow, Iazyki slavianskoi kul'tury. (In Russian)

Pis'mennyi korpus tatarskogo iazyka [The Written Corpus of the Tatar Language]. Elektronnyi resurs. URL: https://www.corpus.tatar/ (accessed: 26.08.2019). (In Russian)

Tatarskii natsional'nyi korpus "Tugan tel" [Tatar National Corpus "Tugan tel”]. Elektronnyi resurs. URL: http://web-

corpora.net/TatarCorpus/search/?interface_language=ru (accessed: 26.08.2019) (In Russian, in Tatar)

Zakamulina, M. N., Lutfullina, G. F., Mullakhmetova, G. R. (2016). Ocherki po aspektologii. Problema realizatsii chastnykh znacheniy (sopostavitel'noe issledovanie na materiale frantsuzskogo $i$ tatarskogo iazykov] [Essays on Aspectology. The Problem of the Realization of Particular Meanings (comparative research based on the French and Tatar languages)]. 244 p. Kazan', Izd-vo KGEU. (In Russian) 


\title{
ТАТАР ҺӘМ ИНГЛИЗ ТЕЛЛӘРЕНДӘ ПАРАМЕТРИК СЫЙФАТЛАРНЫН КУЛЛАНЫШЫ
}

\author{
Гөлнара Фирдәвис кызы Лотфуллина, \\ Казан дәүләт энергетика университеты, \\ Россия, 420034, Казан ш., Красносельск урамы, 51 нче йорт, \\ gflutfullina@mail.ru. \\ Рүзилә Рәшит кызы Сәлахова, \\ Казан федераль университеты, \\ Россия, 420008, Казан ш., Кремль ур., 18 нче йорт, \\ ruzilya5@mail.ru. \\ Гүзәл Зөфәр кызы Гыйләжиева, \\ Казан дәүләт энергетика университеты, \\ Россия, 420034, Казан ш., Красносельск урамы, 51 нче йорт, \\ gilyazieva78@mail.ru.
}

\begin{abstract}
Әлеге мәкаләдә кеше тирәлегенә бәйле булган параметрик сыйфатлар чагыштырма аспектта тикшерелә. Предметларның номинатив үлчәмен тасвирлый торган сыйфатларны татар hәм инглиз телләре яссылыгында тикшерү һәр ике телнең лексикасына, семантикасына кагылышлы байтак мәсьәләләргә ачыклык кертү белән бергә, төзелеше ягыннан төрле булган ике телдәге уртак həм аермалы якларны күрсәтергә, аларның сөйләмдә кулланылыш ешлыгын билгеләргә мөмкинлек бирә. Теманың хәзерге тел белемендә актуальлеге шуның белән аңлатыла.

Мәкалә кешенең тышкы кыяфәтен, кием-салымын тасвирлый торган сыйфатларның төп үзенчәлекләрен фәнни яктан өйрәнүне максат итеп куя. Тикшерелә торган адъективларга зур, киң, кечкенә, вак, озын, кыска кебек берәмлекләр алына, аларның сөйләмдәге үзенчәлекләрен ачыклау өчен мисаллар татар (Tatar National Corpus «Tugan Tel») həм инглиз (British National Corpus) телләренең милли корпусларына мөрәжәгать ителә. Корпустан тупланган фактик материал нигезендә күрсәтелгән параметрик сыйфатларның уңай hәм тискәре төрләре ачыклана.

Фәнни-тикшеренү эшенең нәзари һәм гамәли әһәмияте тәкъдим ителгән материалны татар həм инглиз телләрен укыту методикасында куллану, шулай ук мәкаләдәге төп нәтижәләрне телнең лексикологиясен, семасиологиясен, стилистикасын өйрәнүгә юнәлдерелгән хезмәтләрдә файдалану мөмкинлеге белән билгеләнә.
\end{abstract}

Төп төшенчәләр: параметрик сыйфатлар, уңай параметр сыйфатлары, тискәре параметр сыйфатлары, сүзтезмә, кулланылыш ешлыгы.

Тел жәмгыять яшәеше белән тыгыз бәйләнгән. Телдә кеше эшчәнлегенең төрле яклары hәм эш вакытында аның жәмгыять, табигать, әйләнә-тирә белән мең төрле мөнәсәбәтләре чагылыш таба. Әлеге мөнәсәбәтләрне тел берәмлекләренең семантик үзенчәлекләрен жентекләп өйрәнү нәтижәсендә генә ачыкларга мөмкин. Татар телендә кеше hәм аңа якын тирәлектәге предметларның тышкы билгеләрен, пространствога бәйле төрле мөнәсәбәтләрен характерлый торган сыйфатларны махсус өйрәнгән фәнни хезмәтләр юк. Мәгьлүм булганча, предметлар доминант параметр буенча характерланалар. Мәсәлән, биек йорт, йорт төзелешенә куелган стандарттан биегрәк булып күренә, әгәр йортлар зур һәм озын булсалар, аларны тасвирлаганда

кулланылмый [1, 3]. Ономасиологик алым предметларның сыйфатын капма-каршы юнәлештә, ягъни чагылыш планыннан эчтәлек планына таба өйрәнүне күздә тота. Эчтәлек планына семасиологик якын килү, нигездә, сыйфатларның билге белдеру үзенчәлеген ачыклауга корыла. Әлеге мәкаләнең фәнни яңалыгы - кеше тирәлегенә бәйле булган предметларның күләмен белдерә торган билгеләрне ономасиологик алым кулланып, чагыштырма аспектта тикшеру. Димәк, хезмәтнең өйрәнү объекты итеп - сыйфатлар, тикшерү предметы буларак сыйфатларның эчтәлеге hәм тасвирланышы алынды. Кешеләрнең көнкүрешенә, яшәү тирәлегенә бәйле киңлек параметрларларын анализлауда 
Г.И. Кустова тарафыннан тәкъдим ителгән алым кулланылды [4].

Беренче чиратта кешегә «якын тирәлекне»не тәшкил итә торган параметрик сыйфатларга тукталыйк. Кием-салым, бизәнү әйберләре контакт параметрлары булып саналалар [2]. Әлеге предмет параметрлары турыдан-туры кешенең үзенә карата кулланылмый, әмма алар прототипик үлчәү билгесенә ия булып торалар. Ягъни кешеләр бу әйберләрне кулланганда, үзләренең гәүдә үзенчәлекләрен исәпкә алып, аларның озынлыгына, киңлегенә, зурлыгына игътибар итәләр. Мәсәлән, озын муенсалар муен үзенчәлекләренә карап сайлана, озын күлмәкләр яки чалбарлар кигәндә буй һәм аяк озынлыгы исәпкә алына. Мисал өчен бизәну әйберләрен карап үтик:

Итәк очы алтын чачаклы ак атлас күлмәк, алтынсу ефәк билбау, жсиц очлары, яка турлары ука белән чигелгән куе кызыл төстаге бәрхет камзул кигән, муенга затль каптырма белән эләктерелгән, эре тамгаль энжсебриллиантлар белән зиннәтләнгән киң муенса, башына жсем-жсем килеп торган, энжсебриллиантлар белән бизәлгән, очьл уң якка сальнып торган калфак кигән (М. Галиев. Талисман) [10].

Ак батист яульгын кара кашлары өстеннән генә артка кайтарып бәйләгән, якасы ачыкк, кыска жстиле тар күлмәк киеп, ж⿻ыерчыклы муенына вак мәржсәнндн кечкено муенса таккан, симез беләгенд кара көмеш беләзек кигән (Ә. Еники. Саз чәчәге) [10].

If their complexion was their most celebrated feature, then perhaps a long necklace of perfect pearls (8S2) [6].

Bare shoulders and arms; a heavy gold and ebony bracelet; an enormously long necklace of what looked like sapphires, though I presumed they must be paste (G13) [6].

Югарыда телгә алынган бизәнү әйберенең озынлык параметры кешенең муен үзенчәлекләренә бәйле рәвештә карала. Татар телендә муенса сүзе 109 тапкыр очрый, әмма параметрик сыйфатлар белән кулланылган очракка ике генә мисал табылды: киң муенса, кечкенә муенса. Инглиз телендә, мәсәлән, муенса параметрик сыйфат белән бик сирәк характерлана: long necklace ике урында күзәтелде, ә short necklace сүзтезмәсе бөтенләй очрамады. Шулай итеп, татар телендә муенса өчен озынлык параметры мөһим роль уйнамый. Бу исә халык аңында традицион рәвештә кулланылып килгән ниндидер стереотип озынлык барлыгын искәртә.

\section{Кием-салым}

Кәрим абый киңушен истә тотыл, өстемә киясе нәрсәләрне сайлап алдыл: кара бәрхеттән тар гына озын күлмәк, биек Үкчәле туфлиләр, кечкенә энжселе калфак (Ә. Еники. Гөләндәм туташ хәтирәсе) [10].

Мәрьямбану бөтен тәнен каплап торган озын күлмәк кигән, башына, чәч муены күренмәслек итеп, ак яульк бөркәнгән (Ф.Бәйрәмова. Соңгы намаз) [10].

Ә яныңда торган авыл кызыныңң черкиләргә исе дә китми, бары тик ара-тирә генә болай да кыска күлмәк итәген күтәреп, ак балтырларына кунган әдәпсез черкинен башына жситә (Н. Әхмәдиев. Амбирак, яки кара каен кыйссасы) [10].

Ак төстәге кыска чалбар кигән, жсицсез блузкасын да жсилкәсенд эленгән ике тар тасма гына mombln mopa (М. Әмирханов. И кылган догам минем) [10].

Бәлки, алар колхозыныңң сыерларыннан сауган сөтләр дә менә шулай шешәләр белән монда киләдер дә, аның кем кульннан чыкканыл уйлап тормастан, тездән югары кыска чалбар кигән, кара күзлекле, жсонль балтырль иушы адәмнәр эчеп куялардыр (М. Мәһдиев) [10].

Sounds like she's got a flipping long dress on and a straw hat (KCE) [6].

We had works big ball in the wintertime, when you went with your long dress on, and your gloves, you know your (H05) [6].

Mrs Lynde looked at the thin little girl in the short dress, with her freckled face and red hair (FPT) [10].

Lower at the back, the short dress's absolute simplicity contrasted effectively with the extravagant colour, a deep rich crimson (H9L) [6].

Because he always had long trousers that went over his boots, and they were you know, very wide (G64) [6].

(2) They were real grown-up long trousers exactly like those worn by the boys at the big school (ACW) [6].

Гадәти хатын-кыз киеме озынлыкны билгели торган параметрик сыйфатлар белән белдерелә, югарыда искәртелгәнчә, алар кешенең буй озынлыгына карап билгеләнәләр. Тикшеренүләрдән күренгәнчә, hәр ике телдә дә уңай параметрлы сыйфатлар, тискәре параметрик сыйфатлардан аермалы буларак, 45 тапкыр күбрәк кулланылган. Татар һәм 
инглиз телләрендәге параметрик сыйфатларның кулланылыш ешлыгын чагыштырма планда анализлау нәтижәләре бу төр сыйфатларның инглиз телендә 2 тапкыр кимрәк кулланылуын күрсәтте. Мисалларны карап китик: long dress 22 тапкыр, татар телендә: озын күлмәк - 39 тапкыр. Тискәре параметрлы сыйфатларларның кулланылыш ешлыгына килгәндә, алар ике телдә дә бертигез дәрәжәдә очрый: short dress 5 тапкыр, кыска күлмәк - 7 тапкыр. Шунысын да билгеләп китү мөһим: татар телендә күлмәк озынлыгының стандарт параметрлары инглиз телендәге параметрлардан күпкә артыграк, бу исә татар халкының традицион киемнәре арасында озын күлмәкнең уңай коннотациягә ия булуына бәйле.

Чалбар, гадәти ир-ат киеме буларак, очраклы рәвештә алынмады, чөнки аның озынлыгы гәүдәнең боттан алып тубыкка кадәр булган өлешенә карап билгеләнә. Татар телендә чалбарны озынлыгы буенча характерлау бик аз күләмдә бирелгән: озын чалбар - 1 тапкыр, кыска чалбар - 6 тапкыр. Инглиз телендә тискәре параметрик сыйфат 2 тапкыр артыграк кулланылган: long trousers - 13 тапкыр, short trousers - 29 тапкыр. Әлеге сыйфатның кулланылышы тискәре бәя бирүне күз алдында тота, чөнки чалбар озынлыгының стандарт параметры боттан алып тубыкка кадәр булган ара озынлыгына туры килергә тиеш.

\section{Баш киеме}

Тавышка зур мамык шәл ябынган әнисе ут

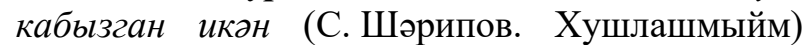
[10].

Януагын зур яульк белән бдйләгән Шәйхетдинов керә (Т. Гыйззәт) [5].

Башына ул чәчен бергә туплап кыска гына яульк бәйләп куйган, өстенә эре чәчкә төшерелгән кыска итәкле ситсы күлмәк һәм иркен балакль озын чалбар - спортсменнар чалбары киеп куйган иде (Н. Фәттах. Сайланма әсәрләр) [10].

Why did they last minute put this long scarf round her neck, hmm? (8S2) [6].

All I know is he he has big, protruding eyes and he wears a funny-looking, short, white scarf (ACW) [6].

Тикшеренү нәтижәләре күрсәткәнчә, инглиз теле белән чагыштырганда, татар телендә хатын-кыз баш киеменең күп кулланылган булуы ачыкланды, әлеге факт татар халкының милли һәм дини үзенчәлекләре белән аңлатыла. Уңай параметр сыйфатларыннан зур яулькк (шәл) - 17 тапкыр, кире параметрик сыйфаты кыска яульк - 4 тапкыр очрый. Кечкенә яулькк кебек сүзтезмәләр дә күзәтелде, әмма аларда яульк сүзе кульяулык мәгънәсендә кулланылган. Биредә шуны да искәртеп китү мөһим: татар хатын-кызлары яулык яки шәл өстеннән калфак та кигәннәр. Калфак берәмлеген ачыклап килгән сыйфатлар, гадәттә, әлеге милли баш киеменең бизәлешен, төсен, кыйммәтлелеген ассызыклыйлар; әмма, сирәк кенә булса да, кечкенә, нәни кебек тискәре параметрик сыйфатлар белән кулланылган очраклар да бар:

Кызның башында - төсе һаман Үзгәрмәгән нәни ямел калфак (Р. Гариф Үлмәсбикә) [10].

Кечкенә генд калфак кия, amacbl күрмәгәндә мандолина уйнап та ж⿻ибәрә (Г. Ибраһимов. Яшьләр) [10].

Инглиз телендә шарф еш кына хатынкызның баш киеме буларак очрый, ул күптөрле сыйфатлар белән билгеләнә, әмма аның параметрик сыйфатлар белән кулланылышына мисаллар бик аз табылды. Шарф, нигездә, озынлык параметры буенча характерлана [8, 9]. Безнең күзәтүләрдә озын шарф унай параметрик сыйфат булып санала, ул 6 тапкыр очрады, тискәре билгегә ия булган кыска шарф сүзтезмәсе 3 тапкыр очрады.

\section{Аяк киеме}

Kысыл торган яисә артык зур аяк киеме сәламәтлек өчен зыянль (А. Ситдыйкова. Сәламәтлек - үкчә астында!) [10].

Аягына кап-кара зур итек, өстенә алама сырма, башына йолкыш бүрек кигән мыекль ир стройдан йөгереп чыга да, тезен кочаклап, жсепшек карга иелә (С. Шәрипов) [10].

She thinks she's tall. Look at him big shoes So what, so what say it right here (KPE) [6].

Half consisted of a short, black skirt and plump legs tapering to absurdly small shoes (GW3) [6].

The only blots on the landscape were a pair of small shoes beside the Aga and a nylon ski-jacket airing on the back of a chair (JYC) [6].

Безнең фикеребезчә, ир-ат һәм хатын-кыз аяк киемнәренә аерым анализ ясау ихтыяжы юк, чөнки ике очракта да аяк киеменең үлчәме аяк табаны зурлыгы белән билгеләнә. Шуның өстенә, татар телендә дә, инглиз телендә дә аяк киеменең зурлыгын характерлау бик сирәк күзәтелә: big shoes - 1 тапкыр, small shoes - 2 тапкыр, зур аяк киеме - 6 тапкыр, кечкенә аяк киеме - 1 тапкыр. Инглиз теленнән аермалы буларак, татар телендә итек сүзе бик еш кулланылган (551 тапкыр). Алар арасында озынлык үлчәме белән тасвирланган бер генә 
параметрик сыйфат табылды һәм әлеге параметр аякның тубык озынлыгына карап билгеләнә. Димәк, аяк киеме һәм аның үлчәме, нигездә, аяк табаны параметрына тәңгәл.

Кунычлы аяк киемнәрендә, мәсәлән, итек сүзендә, параметрик сыйфатларның бүтән төрләрен дә күрергә мөмкин:

Лесниковның аягында - озын итек, буыннары ялгана торган спиннинг тагылган жесенен беләгенд элгән, ж⿻ылырык кингән (С. Шәрипов. Хушлашмыйм) [10].

Итек сүзе татар телендә, бик еш күзәтелүенә карамастан (551 тапкыр), параметрик сыйфатлар белән сирәк кулланылган. Соңгы мисалда тәкъдим ителгән параметрик сыйфат (озын итек) аякның тубык озынлыгына карап билгеләнә. Татар теленә бәйле тагын бер кызыклы үзенчәлекне искәртеп китү зарур: биредә башмак (59 тапкыр), чүәк (24 тапкыр) кебек аяк киемнәре бик күп очрый, әмма аларның параметрик сыйфатлар белән кулланылган очраклары күзәтелмәде.

\section{Ризык}

«Ризыкны матди яктан карап була, аның үз авырлыгы бар, кеше аны үз өстендә йөртмәсә дә, эчендә йөртә,» - дип искәртә И.Г. Кустова [4: 144]. Ризыкларны характерлый торган гомуми билгеләр жыелмасы бар, шул сәбәпле алар өч үлчәмле параметрик сыйфатлар белән сирәк белдереләләр. Мәсәлән, зур торт дигәндә, әлеге ризыкның зурлыгына түгел, бәлки бәйрәмнең масштабына басым ясала. Татар һәм инглиз телләрендә big mac, вак бәлеш сүзтезмәләре бик еш очрый, әмма бу очракта big, вак кебек сыйфатлар әлеге ризыкларның зурлыгын белдерми, чөнки həр икесе ризык атамасы составында кулланылалар.

Well we don't have it on Sunday because we always have a great big lunch (KBB) [6].

I can't eat it I don't think so he had a big lunch (KCV) [6].

Югарыда китерелгән мисаллардан күренгәнчә, инглиз телендә big сыйфатын Макдональдс ризыклары исемлегедә бик еш очратырга мөмкин big mac, big tasty h.б. Кулланылыш ешлыгына килгәндә, инглиз теле корпусында иң күп очрый торган сүзтезмә - big $m a c$, ул 41 тапкыр кулланылган, икенче урында 6 мәртәбә күзәтелгән big lunch сүзтезмәсе. Алар икесе дә уңай параметрик сыйфат булып саналалар.

Бәйрәм торты да инглиз телендә зур үлчәмнәр белән сирәк характерлана: big cake 6 тапкыр, ә small cake 12 тапкыр очрый.
Күргәнебезчә, биредә тискәре параметр сыйфаты өстенлек итә, әмма кечкенә үлчәмне белдерә торган cup cake сүзтезмәсенең барлыгын да искәртеп китү мөһим.

Табын уртасына хуш исләре аңүкып торган чөләкле зур болеш чыгарылды (Р. Низами. Без яшибез) [10].

Квартирга кунак егет кайтасы булгач, Гайнелвафа карчык бозауны абзарга чыгарган, can-сары итеп баскычларны, идәннәрне юган, вак болеш пешергән иде (М. Мәһдиев. Фронтовиклар) [5].

Карчык кишерне турап, аңардан зур бәлеш пешергән (С. Сәүбанова. Әкиятләр) [10].

Ак әби иртән Гыйлемдарны вак пәрәмәч белән сыйлады (А. Тимергалин. Караурман аша) [10].

Вак кына күмәч яки бавырсак (Гаяз Исхакый. Кәжүл читек) [10]. Мисаллардан күренгәнчә, татар телендә ризык параметрларын билгели торган сыйфатлар арасында вак сыйфаты өстенлек итә, әлеге сыйфат 2692 тапкыр очрый. Параметрик сыйфатлар күбесенчә (зур бәлеш, вак бәлеш) ризык атамасы составында кулланылганнар. Соңгы өч жөмләдә билгеләнгән сүзтезмәләрдә генә (зур бәлеш, вак пәрәмәч, вак бавырсак, вак күмәч) ризыкның параметрик билгесен белдереп килгәннәр.

Шулай итеп, тикшеру барышында тоташ сайлау методы ярдәмендә тупланган параметрик сыйфатлы 300 сүзтезмәгә анализ ясалды һәм аларның күпчелек өлешен ризык атамалары тәшкил итә.

Татар телендә мәжлеснең әһәмиятен, зурлыгын билгели торган төп ризык булып, инглиз теленнән аермалы буларак, торт түгел, ә бәлеш санала. Димәк, логик яктан ул уңай параметр сыйфаты белән характерланырга тиеш, әмма зур бәлеш сүзтезмәсе нибары 5 тапкыр гына очрады. Безнең фикеребезчә, әлеге милли ризык атамасының исеме үк аның зурлыгын билгели. Бу гипотеза тискәре параметр сыйфатының вак бәлеш сүзтезмәсендә ешрак куллануын аңлата: вак бәлеш - 16 тапкыр. Калган сүзтезмәләр бик сирәк күзәтеләләр, мәсәлән, вак пәрәмәч - 3 тапкыр. Зур пәрәмәч сүзтезмәсе бөтенләй кулланылмый. Биредә шуны да искәртеп китү мөһим: камыр ашларын характерлаганда вак сыйфаты аларга тискәре бәя бирми, бары тик аларны нейтраль яктан гына төсмерли. Калган очракларда, мәсәлән, башка төрле ризыкларга бәя биргәндә, 
тискәре параметр сыйфатлары, гадәттә, негатив бәя буларак күзалланалар.

\section{Кешенең тән төзелеше}

Параметрик сыйфатлар белән гадәттә кешенең гәүдәсе дә, тән әгъзалары да тасвирлана. Кешенең гәүдә зурлыгы озын һәм mаза кебек сыйфатлар ярдәмендә характерлана, әмма биредә параметрик характеристиканың кешенең үз күзаллавыннан, үз-үзен ничек кабул итүеннән чыгып билгеләнүен истә тоту мөһим. Кайбер мисалларны карап китик:

Озын чәч Үстерерга рөхсәт итмилар иде ул чакта (3. Мәхмүди. Хыялый) [10].

Дөрес, кайчагында кистереп атасы килгән минутлары да була кызның, янәсе, кыска чәч булса, мәшәкате әзрәк (А. Әхмәтгалиева. Синең өчен яшим) [10].

Зур күзле, коңзалрт кальн тольмльи, төз озын аякль, ап-ак тәнле бер кыз икән (М. Мәһдиев. Фронтовиклар) [10].

Биек күтәртмәле аяк киеме кигән хатынкыз Үзенең тәбәнәк буйль һәм кыска аяклы икәнен күрсәтеп йөри (Р. Батулла. Сайланма әсәрлар) [10].

Эчендәге тылшында булган, уйлаганы шундук теленә чыккан Нурия бала чакта торып калды, аның урынына кинәт сузаеп киткән, озын куллы, озын аяклы, озын муенлы (абау!) берәу пәйда булды (Г. Якупова. Ерткыч каны) [10].

Жыелганнар ярым көлемсерәп бер-берсенд караштылар, түрда утырган, шара тәне зәнугәр сурәтләр белән бизәлгән, киң күкрәкле, кыска куллы банда черт итеп төпчеген почмакка очыртыты (А. Гыйләжев. Балта кем кулында?) [10].

Югарыда искәртелгәнчә, озынлык, биеклек hәм киңлек - контактка бәйле булмаган билгеләр. Аларны очратып була. Әгәр предмет озынлык параметрына туры килсә, ул озын сыйфаты белән белдерелә. Күп кенә предметлар чагыштыру нәтижәсендә генә озынлык билгесенә ия булалар. Мәсәлән, озын тольмм сүзтезмәсен алыйк, ул икенче бер толымнан озынрак булуы белән аерылып тора:

Кылану гына булган икән, бераздан каядыр жсыенгандай кинәт тураеп, озын кара чәч тольмнарын рәтләргә кереште (З.Мәхмүди. Серле кунак) [10].

Икесенда дә кыска тольм, аякларында килешле кәттә чүәкләр, өсләрендә жсинел чуар күлмәк (Н. Каштанов. Паромда) [10].

Инглиз телендәге мисалларга игътибар итик:
He's got long hair and all (KB1) [6]. [6].

Short hair or long hair or just a man? (KCV)

Short hair like a bit of a moron? (KDM) [6].

You'll grow up to be an ugly wizened little monster with short arms and a big head (ACW) [6].

On the landing a new thought occurred to her and she re-entered, her long arms swinging, her face screwed up with anger (ASS) [6].

It was summer and the only time the air moved was when Zervos waved his short arms or a truck went past outside (C86) [6].

His big body and large head topping the back of it while his short legs hardly touched the floor (CK9) [6].

I can imagine you in a tennis dress. You have such long legs." My knees are knobbly,' she said firmly (A0R) [6].

Ике телдәге күзәтүләрдән чыгып, түбәндәге нәтижәләрне ясарга мөмкин.

Кеше тәне әгъзалары атамалары һәм параметрик сыйфатлардан торган сүзтезмәләр төркеме ике телдә дә күп кулланылган. Алар кешенең тышкы кыяфәтен аерым бер билге буенча характерлыйлар. Теге яки бу тән әгъзаларының билгеле бер эстетик нормалардан чагыштырмача зуррак яки кечерәк булуы кабул ителгән стериотипны боза, мәсәлән, зур башльы, озын колакль һ.б. Этика нормалары теге яки бу тән әгъзасының озынлык параметрына туры килмәвен бәяләмичә, нейтраль рәвештә аңлатуны күздә тота.

Инглиз телендә дә кешенең тән әгъзаларын озынлык параметры ягыннан тасвирлый торган сыйфатлар саны байтак [7]. Тикшеренү нәтижәләреннән күренгәнчә, әлеге телдә, нигездә, уңай параметрга ия булган сыйфатлар өстенлек итә. Мисал өчен, кешенең кул озыллысылн белдергән сыйфатларның 3 тапкыр, аяк озынлыгын чагылдырган сыйфатларның 5 һәм чәч озынльгын тасвирлаганнарының 2 тапкыр артыграк кулланылышы күзәтелә.

long hair - 271 тапкыр; short hair - 109 тапкыр;

long arms - 33 тапкыр; short arms - 11 тапкыр;

long legs - 155 тапкыр; short legs - 30 тапкыр.

Сүзтезмәләрнең күпсанлы булуын кешеләрнең үз-үзләренә һәм тирә-юньгә игътибарлы булулары белән аңлатырга мөмкин.

Татар телендә кешенең тән әгъзаларын тасвирлый торган параметрик сыйфатларның 
кулланылыш ешлыгы, инглиз теле белән чагыштырганда, 5 тапкыр кимрәк:

озын чәч - 47 тапкыр; кыска чәч - 11

тапкыр;

озын аякль - 34 тапкыр; кыска аякль - 20

тапкыр;

озын кулль - 19 тапкыр; кыска куллы - 1 тапкыр.

Шунысы да игътибарга лаек: татар телендә аякны тасвирлый торган тискәре параметрик сыйфатларның күпчелек өлеше теге яки бу предметка (мәсәлән, кыска аяклы өстәл һ.б.) яки хайваннарга (кыска аяклы эт яки сыер һ.б.) карата аеруча еш кулланылган.

Татар мәдәниятендә кешенең тышкы кыяфәтенә зур игътибар бирү кабул ителмәгән, кеше кыяфәтенә караган параметрик сыйфатларның сан ягыннан ким булуы да нәкъ менә шушы үзенчәлеккә бәйле дип саныйбыз.

Кешенең йөз кыяфәте төрле сыйфатлар белән характерлана ала. Йөз-кыяфәтнең гомуми үлчәме аның башка өлешләренең, мәсәлән, зур (тар, киң) маңзай, зур (кечкенә) күз, зур (озын, nочык) борын параметрларын билгели торган күрсәткеч булып тора. Китерелгән мисалларда киң, зур, озын кебек параметрик сыйфатлар йөзкыяфәт параметрыннан (зурлыгыннан) чыгып билгеләнгән.

Теге-бу турында сөйләштеләр, көлештеләр, ләкин яңадан музыка уйный башлагач та, зур борынлы егет беренче бульп Рафиганың кульгннан тотып та алды, жсилтерәтеп, бөтерелдереп, уртага кереп тә китте (Н. Фәттах. Сайланма әсәрләр) [10].

Гуд бай! - дип хәтәр янады калун балта йөзедай рәхимсез чырайлы, зур борынлы латыли һәм куркытып чыгып та киттеләр (Х. Камалов. Сайланма әсәрләр) [10].

Дүрт ай узгач та, күрше Миңлебикә абыстай Татаның үзенндн ун яшь чамасы яшьрәк, ак кына чырайль, бәрәнге алмасы кебек түгарәк кечкенә борынлы, яшькелт күзле бер хатынны ияртә керде (Ә. Баян. Төлке тоту кыен түгел) [10].

Чөнки безда хәзер кечкенә борынлы яһүдләр, зәнцгәр чәчле татарлар, кысык күзле урыслар һәм сап-сары башлы негрлар күбайде (К. Кәримов. Телеңне күрсәт...) [10].

Аскарак салынган иреннәре белән зур авыз эчендә тезелгән ак, озын тешләр, ут уйнап торган ялкынль зур күзләр, бигрәк тә, ут чыгаргандай каты, үткен, тиз баса торган йомры, кечкенә ялтыр тояклар аның бу киң далада бик күп ж⿻ылкыларга алын бирмәс йөгереклеген күрсәтәләр (Г. Ибраһимов. Казакъ кызы) [10].

Үзе кебек үк зур күзле, олырак авызлы томрап торган улы дөньяга килгәндә, Әхтәри Берлин янында, бәләкәй генә зиратта, чит илнең салкын туфрагында ята иде инде (А. Гыйләжев. Тәрәзәләр) [10].

Кечкенә авыз, сусыл иреннәр, гүя ул салам кабып затлы коктейль йотарга гына яратылган (С. Шәрипов Хушлашмыйм) [10].

Рамил ул арабызда иң озын буйль, зур башлы, зур күзле, киң иңсәле таза һәм батыр малай (Р. Фәизов. Без - өч дус) [10].

Ул мәжслестә кечкенд күзле бер бала бар иде (К. Насыйри. Сайланма әсәрләр) [10].

Чиертсәң кан чыгарга торган кып-кызылл чырайль, дуңзгызныкы кебек кенд кечкенд күзле юан майор акыра икән (И. Сиражи. Бер утыру бер гомер) [10].

Татар телендә уңай параметрлы сыйфатлар борын һәм күзләрне тасвирлаганда аеруча күп очрый, аларның авыз һәм колак кебек әгъзаларны белдергән параметрик сыйфатлардан аермалы буларак, 3 тапкыр ешрак кулланылган булуы ачыкланды.

зур борынлы - 31 тапкыр; кечкенә борынль $-5$

зур күзле - 34 тапкыр; кечкенә күзле - 5; бәләкай күзле - 0;

зур авыз - 11 тапкыр; кечкенд авыз - 1 тапкыр;

зур колаклы - 11 тапкыр; кечкенә колакль 2 тапкыр.

Инглиз телендәге мисалларны карыйк:

He's got a big nose got big ears (KP3) [6].

Boyfriend said I'm a common cow and have a got a big nose (KPG) [6].

Moxie, was curly and glossy, his face with high cheek bones and small nose and small sensuous mouth and dark blue eyes, had resumed its glowing charm (APM) [6].

Her features were classically beautiful: the perfectly structured high cheekbones, a small nose, sensual mouth and mesmerizing oval- shaped green eyes (ECK) [6].

She don't say nothing to me, she just looks at me with these big eyes (A74) [6].

Dark girl dressed in scarlet who had a big head, big eyes (her best feature), a big nose and a very big voice ( $\mathrm{ABW})[6]$.

A slow deliberate talker, he fixed his small eyes on the subject he was conversing with, as though exerting a hypnotic effect (ARK) [6]. 
Cynthia and her father coloured hotly, Basil glowered, and Mrs Blessington-Dalrymple's small eyes snapped angrily (BMU) [6].

I love your hairy chest, I love your bi-but I love your big ears, I love you (KB8) [6].

Big nose, big ears, big, big mouth! (KDA) [6].

God had never invented a woman with small ears! (KD8) [6].

It stuck tiny thumbs in small ears, wagged its fingers, and put out its tongue (CEU) [6].

Инглиз телендә йөз-кыяфәтне тасвирлый торган сүзтезмәләр төркеме киң таралыш алган. Югарыда китерелгән мисаллардан күренгәнчә, уңай параметрик сыйфатлар йөз-кыяфәтнең барлык өлешләрендә дә бертигез кулланылалар. Тискәре параметрга ия булган сыйфатларны борын, колак һәм авыз, күз кебек әгъзаларны тасвирлаганда күзәтергә мөмкин, әмма алар, кулланылыш ешлыгы ягыннан, уңай параметрик сыйфатлардан күпкә калышалар. Мәсәлән, борынга бәйле тискәре сыйфатлар - 4, колакларны тасвирлаганнары - 10, авызны сурәтли торганнары 3 тапкырга кимрәк очрый. Бары тик күзләр белән бирелгән сүзтезмәләрдә генә тискәре параметрик сыфатларның, уңай параметрик сыйфатлар белән чагыштырганда, 3 тапкырга артыграк кулланылышы ачыкланды:

big nose - 27 тапкыр; small nose - 7 тапкыр; big eyes - 33 тапкыр; small eyes - 21 тапкыр; big ears - 49 тапкыр; small ears - 4 тапкыр; big mouth - 50 тапкыр; small mouth - 15 тапкыр.

Шулай итеп, инглиз телендә кешеләрнең йөз-кыяфәтен тасвирлауга зур игьтибар бирелә hәм аның аерым өлешләре параметрик сыйфатлар ярдәмендә жентекле рәвештә тасвирлана.

Ике телнең дә кеше тирәлегенә якын булган параметрик сыйфатларын тикшергәннән соң, түбәндәге нәтижәләр билгеләнде:

- Параметрик сыйфатларның семантик үзенчәлекләре гаять катлаулы. Биредә, иң беренче чиратта, теге яки бу предмет билгесенең стандарт параметрларын ачыклау мөһим. Стандарт билгеләргә туры килсә, предметның сыйфаты уңай характерлана, туры килмәсә, тискәре параметр буларак карала. Әмма бу параметрларны hәр халык үзенең күзаллауларыннан чыгып билгели. Мәсәлән, татар халкының милли ризыгы булган вак бәлеш атамасында кулланылган тискәре параметрик сыйфат биредә ризыкның үлчәмен белдерми, ләкин башка халык аны нәкъ менә тискәре параметрик сыйфат итеп кабул итәргә мөмкин.
Кайбер предметларның параметрик билгеләре зур һәм кечкенә белән генә чикләнми, аларга киң, тар, озын, кыска кебек сыйфатлар да хас була. Параметрик сыйфатлар күбрәк булган саен, предметның эчтәлеге тулырак ачыла. Биредә бер үк параметрларны белдергән синонимик (зур, ольl, дәү; кечкенә, бәләкәй, нәни) яки антонимик сыйфатларны (зур - кечкенә; озын - кыска) да истә тотарга тиешбез. Шуңа күрә, югарыда искәртелгәнчә, параметрик сыйфатларны ономасиологик алым кулланып тикшерү зур әһәмияткә ия булып тора. Бу алым параметрик сыйфатларның күчерелмә мәгънәләрдә дә кулланылышын ачыкларга мөмкинлек бирә. Мәсәлән, әгәр тән төзелешенә караган мисалларны алсак, татар теле корпусында киң авblзлы, тар aвblзльl, зур aвызлы кебек мисаллар кешегә карата түгел, ә башка предметларга карата кулланылганнар. Мәсәлән: Кечкенд гена, тар авызлы кувшин иде ул (Р. Сәгъди. Ирдәүкәләр) [10]. Шулай да табактай олы авызлы кәкре торбаларны һәм аккош муеныдай сыгылмалы скрипкаларның ни икәнен аера иде (Р.Низами. Без яшибез) [10]. Мондый мисаллар инглиз телендә дә байтак hәм, безнең фикеребезчә, аларны тикшерүгә багышланган аерым фәнни хезмәтләр булырга тиеш.

- Параметрик сыйфатларның төзелешенә килгәндә, аларның структур үзенчәлекләре hәр телнең, безнең очракта, татар һәм инглиз телләренең, үзенчәлекләреннән чыгып билгеләнә. Биредә уртак яклар күп, әмма аермалы яклар да юк түгел. Мәсәлән, татар телендә кешенең кыяфәтен, тән төзелешен тасвирлау, нигездә, кушма сыйфатлар ярдәмендә башкарыла. Мондый төр параметрик сыйфатлар сүзтезмә + -лы/-ле моделе буенча сүзтезмәнең, кушымча алып, кушма сүзгә күчү ысулы белән ясалалар: озын куллы, зур күзле, кыска чәчле һ.б.

- Параметрик сыйфатларның һәр ике телдә кулланылыш ешлыгына да игътибар ителде һәм нәтижәләр статистик алым ярдәмендә яктыртылып барылды. Гомуми нәтижә ясап әйткәндә, татар hәм инглиз телләрендә бу юнәлештә аермалы яклар күбрәк ачыкланды. Мәсәлән, hәр ике телдәге кешенең йөзкыяфәтен тасвирлый торган сыйфатларның гомуми санына килсәк, татар телендә параметрик сыйфатларны белдергән сүзтезмәләр, инглиз теленә караганда, ике дистәгә кимрәк күзәтелә. Безнең фикеребезчә, әлеге күренешне кеше кыяфәтенә булган 
игътибарсызлык итеп түгел, бәлки татарларның башка бер кешене тасвирлауда күрсәткән тотнаклылыгы дип аңларга кирәктер.

Димәк, параметрик сыйфатлар төркемен билгеләүдә төп нигез булып, предметларның номинатив үлчәмен тасвирлый торган сыйфатларны белдергән тел берәмлекләренең структур һәм семантик билгеләре белән бергә, аларның телдә кулланылыш үзенчәлекләре дә торырга тиеш.

\section{Әдәбият}

Апресян Ю.Д. Исследования по семантике и лексикографии. М.: Языки славянских культур, 2009. Т. 1. Парадигматика. 568 с.

Закамулина М.Н., Лутфуллина Г.Ф., Муллахметова Г.Р. Очерки по аспектологии. Проблема реализации частных значений (сопоставительное исследование на материале французского и татарского языков). Казань: Изд-во КГЭУ, 2016. 244 с.

Кузина И.Ю. О параметризации действительности языковыми средствами в художественном дискурсе (на примере эпистолярного жанра описания авантюрного путешествия) // Вестник Орловского государственного университета. Серия «Но- вые гуманитарные исследования». 2011. № 1 (15). С. 161-165.

Кустова Г.И. Типы производных значений и механизмы языкового расширения. М.: Языки славянской культуры, 2004. 472 с.

Письменный корпус татарского языка [Электронный ресурc]. URL: https://www.corpus.tatar/ (дата обращения: 26.08.2019).

British National Corpus [Электронный pecypc]. URL: http://www.natcorp.ox.ac.uk (дата обращения: 26.08.2019).

Cruse D. A. Lexical Semantics. Cambridge: Cambridge University Press, 1986. $234 \mathrm{p}$.

Dirven R., Taylor J. R. The Conceptualisation of Vertical Space in English: The Case of tall // Topics in Cognitive Linguistics / ed. by B. Rudzka-Ostyn. Amsterdam - Philadelphia: John Benjamins Publishing Company, 1988. P. 379-402.

Kennedy Ch., McNally L. Scale structure, degree modification, and the semantics of gradable predicates // Language. 2005. Vol. 81. № 2. P. 345-381.

Tatar National Corpus. Татарский национальный корпус «Туган тел» [Электронный ресурс]. URL: http://web-corpora.net/TatarCorpus/search/?interface_ language $=r u$ (дата обращения: 26.08.2019).

\section{ПРИМЕНЕНИЕ ПАРАМЕТРИЧЕСКИХ ПРИЛАГАТЕЛЬНЫХ В ТАТАРСКОМ И АНГЛИЙСКОМ ЯЗЫКАХ}

Гюльнара Фирдависовна Лотфуллина, Казанский государственный энергетический университет, Россия, 420034, г. Казань, ул. Красносельская, д. 51, gflutfullina@mail.ru.

Рузиля Рашитовна Салахова, Казанский федеральный университет, Россия, 420008, г. Казань, ул. Кремлевская, д. 18, ruzilya5@mail.ru.

Гузель Зофаровна Гилязиева, Казанский государственный энергетический университет, Россия, 420034, г. Казань, ул. Красносельская, д. 51, gilyazieva78@mail.ru.

В статье в сравнительном аспекте изучаются параметрические прилагательные, которые используются для описания человека. Исследование прилагательных, характеризующих номинативные параметры предметов в татарском и английском языках, позволяет, с одной стороны, углубить наши представления о лексике, семантике обоих языков, а с другой стороны - выявить сходства и отличия разноструктурных языков, частоту их использования в языке. Этим и объясняется актуальность данного исследования.

Цель статьи - научное изучение своеобразия использования прилагательных, характеризующих внешность, одежду человека. Материалом исследования выступают адъективы, представляющие из себя крупные, широкие, короткие, длинные единицы. Для выяснения особенностей их использования в языке примеры берутся из татарского (Tatar National Corpus «Tugan Tel») и английского (British National Corpus) национального корпуса языков. На основании 
фактологического материала, выявленного методом анализа корпусов, были определены прилагательные с положительной и отрицательной семантикой.

Практическая значимость данного научного исследования сводится к использованию его результатов в методике преподавания татарского и английского языков. Результаты настоящей работы можно применять при преподавании таких разделов языкознания, как лексикология, семасиология, стилистика.

Ключевые слова: история татарского языка, «Кысса-и Йусуф», тюркская лексика, религиозная лексика, булгарский период. 